\title{
By accident or by design? Influence of government policies on drivers and barriers of smallholder teak growing in Lao PDR
}

\section{Arvola, Anne M}

2019

Arvola , A M , Anttila , J-P \& Hogarth , N 2019 , ' By accident or by design? Influence of government policies on drivers and barriers of smallholder teak growing in Lao PDR ' , Forests, Trees and Livelihoods , vol. 28 , no. 1 , pp. 34-51 . https://doi.org/10.1080/14728028.2018.1557082

http://hdl.handle.net/10138/310524

https://doi.org/10.1080/14728028.2018.1557082

unspecified

acceptedVersion

Downloaded from Helda, University of Helsinki institutional repository.

This is an electronic reprint of the original article.

This reprint may differ from the original in pagination and typographic detail.

Please cite the original version. 


\section{Abstract}

This study analyses the impact of policy, legal and market conditions, as well as specific incentives on smallholders' interest and success in tree growing between 1990-2015 in Lao People's Democratic Republic (Lao PDR or Laos). A review of previous studies and legal and policy papers established the framework for this study, with primary data then collected from smallholders through semistructured interviews in four villages. The interview questions covered household socioeconomic features, land use, information on woodlots and their management, extension services, and perceptions on drivers and challenges of tree growing in the past and in the future. The findings indicate that high level policy objectives of promoting smallholder tree growing are weak in practice at the district and village levels, and the only incentive of any significance, namely land allocation for tree growing, has become ineffectual due to increased land scarcity and preference for other income sources. Current tree growers intend to mainly preserve their present plantation areas, although their interest to expand tree growing areas is weak, and one third of non-growers see tree growing as a potential livelihood diversification option. If the promotion of smallholder tree growing is to be improved, the land and forest policy - and associated legislation - requires thorough revision and simplification, extension services must be made available, and specific incentives developed to allow smallholders to access land and meet their specific needs.

Keywords: Smallholder tree growing, Lao PDR, Tectona grandis, forest policy, legislation, wood markets, future interest, incentives, extension 


\section{Introduction}

In Southeast Asia the Green Revolution led to substantial forest conversion into agricultural lands in the last decades, but the trend is now turning in countries reaching middle-income status. For example the governments of China and Vietnam have strongly promoted smallholder tree growing and thereby have been able to establish a significant plantation forest resource (Midgley et al. 2017). In the Lao People's Democratic Republic (Lao PDR, Laos), the government has promoted smallholder tree growing since the 1990's but their success has been modest compared to the neighbouring countries. Lao PDR's legislative framework and its bottlenecks have been analysed in detail in recent studies (Smith, Ling, et al. 2017) but the lessons learnt over the years on the drivers and incentives for smallholder tree growing, interactions between enabling and hindering framework factors, and smallholders current views on tree growing require more in-depth analysis.

This paper examines the development of smallholder tree growing in Lao PDR against the policy, legal, socioeconomic and market background, aiming to identify the bottlenecks and flaws in the enabling environment, and to analyse to what extent tree growing is induced by supportive government policies (i.e. by design). The focus is on teak (Tectona grandis) growers, as the species has been strongly promoted among smallholders, and to build a timeline from 1990 to 2015 based on earlier research. The research questions are: 1) How has the enabling environment for forest plantations and smallholder tree growing developed in Lao PDR over the last 25 years, and how have smallholder needs been addressed? 2) How has the tree plantation area and plantation management changed in the case-study villages over the past 25 years? 3) What are the tree growing prospects for the future? and 4) How successful have policies been in promoting tree growing, and how could they be improved if smallholder tree growing 
remains as a priority in forest policies? First, we outline the development of the enabling environment based on a literature review, after which we present the methods and findings from a case study. Finally, we analyse and discuss the successes, and suggest changes needed to policies in order to better support smallholder tree growing.

\section{Evolution of Tree Growing and its Operating Environment in Lao PDR}

\section{Development of Plantation Forestry}

Laos' forest plantation area (timber, rubber, agarwood etc.) has gradually grown from less than 10,000 ha in the 1990's to some 446000 ha in 2016 (Hansen et al. 1997; Earth Systems 2016). The share of trees planted by individual farmers and entrepreneurs in this increase is estimated to be some $47.5 \%$, but the figure is only a rough approximation since only some $10 \%$ of smallholder plantations are registered (Smith, Ling, et al. 2017). Rubber plantations make up more than $50 \%$ of the plantation area increase

Teak (Tectona grandis) is a native species in Lao PDR, and the tradition of growing teak originates from the early $20^{\text {th }}$ century (Phimmavong et al. 2009). The teak area has grown steadily from some 5000 ha in the early 1990's to about 50000 ha today (Earth Systems 2016). Smallholder teak planting booms have been reported in Luang Prabang Province, the first being in the late 1980's to mid-1990's, and the second in the 2000's due to amended land transfer rights, improved infrastructure and market opportunities, and to encouraging results from earlier plantings (Newby et al. 2012). Regional 
mapping in Luang Prabang Province by the ACIAR VALTIP II ${ }^{1}$ programme recorded 15342 ha of smallholder teak plantations in 2015 (Boer \& Seneanachack 2016).

\section{Smallholder Tree Growing Enabling Environment}

The success of policies and incentives that promote smallholder forest plantations depends on the socioeconomic context, the overall policy and market environment, the perseverance of supportive policies, and the relevancy of the incentives to overcome the actual hindrances for tree growing (Lamb 2015). These factors, which can be either enabling or preventing depending on their status, include secure land and tree tenure, land use competition, demand and supply, trade, open and functioning wood markets, access to knowledge and appropriate technologies, and the tradition and acceptance of tree growing among land owners and society (Byron 2001; McDermott et al. 2009; Bauhus et al. 2010). Political and macro-economic stability, removal of structural barriers and market distortions, and the creation of a favourable environment for enterprises are the most effective and economically efficient incentives for long term sustained tree growing (Cossalter \& Pye-Smith 2003; Enters et al. 2006). These factors - in the context of Lao PDR - are discussed in the following sections to establish an overall framework against which case study villages results will be analysed.

\section{Forest Policy Development}

The government of Lao PDR has introduced economic reforms since 1986 transforming the country towards the so-called 'market socialism'. Poverty reduction

\footnotetext{
${ }^{1}$ https://www.aciar.gov.au/project/FST/2010/012
} 
and eradication of shifting cultivation have been high on the agenda from the beginning. The first forestry specific policy objectives for sustainable forest management were formulated in 1989 (Phimmavong et al. 2009). The Socio-economic Development Strategic Plan to the year 2020 and the 5-year plan endorsed in 2001 both strongly promoted tree plantations, with a target area of 134000 ha for the 5-year period up to 2005. The most important forest policy tool to date, the Forestry Strategy 2020 (released in 2005), pledges to restore forest cover to $70 \%$ by 2020 and includes a programme for plantation forestry promotion and development (Prime Minister's Office 2005). The strategy recognizes smallholders' potential contribution in increasing the forest area and economic potential of teak growing. It was designed to support smallholder tree growing using several approaches including extension, supporting farmer organizations, marketing and product development, and providing additional land and financing to farmers. Furthermore, the strategy aims to improve the wood industries' performance and the enabling environment for smallholder tree growing by simplifying regulations. Despite the intentions, the results have been modest so far (Smith, Ling, et al. 2017).

\section{Land Tenure and Allocation}

Economic reforms in 1986 included principles of private ownership of production means and free enterprise (Stuart-Fox 2007), whereby the State is responsible for the centralized management of land, including allocation, but the user-rights are similar to actual tenure rights. In 1990 the inheritance law - followed by the new constitution in 1991 - further strengthened the legal protection of the land user-rights (Bourdet 1995).

The Land and Forest Allocation (LFA) programme and the Land-Use Planning and Land Allocation programme (LUPLA) introduced in 1990's (Ducourtieux et al. 2005) allowed for the allocation of land, including degraded forest land, to individuals 
for productive purposes (Lestrelin et al. 2013). Several decrees and directives refined the LUPLA objectives to promote allocation of land for tree plantations, with fast growing species and teak specified as being preferred species. Other refinements included the introduction of land tax exemptions for registered plantations and agroforestry systems with $>1100$ trees per ha and larger than $>1600 \mathrm{~m}^{2}$, exemptions on wood sales royalties and charges for planted forests and agroforestry systems, and the introduction of procedures for tree plantation registration (Smith, Barney, et al. 2017).

After LUPLA, agricultural land area per family was often smaller than before (Ministry of Agriculture and Forestry 2010). To access more land a household could enter into an agreement to manage degraded forest or non-forest land for agriculture, forestry and livestock production. Permanent tenure of the degraded lands could be received after three years if the conditions of the contract are met. Any tree planted belongs to the individual or organisation who planted it, provided they have state recognition and the required approvals or licences for utilization (Sacklokham \& Dufumier 2006; Smith, Ling, et al. 2017).

\section{Forest Law and regulations}

The role of forest legislation (National Assembly 1996; Lao People's Democratic Republic 2007, presenty under revision) in promoting smallholder tree growing has been complementary to the land allocation process. In addition, some specific financial incentives have been introduced for forest plantations. However, regulation on smallholder tree growing has remained a complication. For example, smallholder forest plantations are included in the production forest category, and despite the regulatory reliefs for plantation wood trade and taxation, there have been conflicting 
interpretations of the regulations as they apply to planted forests. Non-compliance is common, since even the authorities responsible for law enforcement are not clear about how to apply the complicated and overlapping regulations, and the costs associated with compliance are excessive against expected returns (Smith, Barney, et al. 2017).

\section{Agricultural Expansion and Competition of Land Uses}

Growing demand from China and Vietnam for various agricultural products (Andersson et al. 2009) has supported agricultural intensification and diversification, but it has also led to expansion of shifting cultivation areas in northern Laos (Hurni et al. 2013). There is much local variation, and variation over time in these agricultural 'boom crops'. Rubber expansion, which started in the early 2000's, continues (Phompila et al. 2017) in northern Laos mainly through contract farming arrangements between companies and smallholders (Cramb et al. 2015). Cash crop production area has increased significantly in recent years, including sugar cane, coffee, maize, cassava, banana, and eucalyptus (see for instance Kallio et al. 2019).

\section{Wood Demand-Supply Balance}

Access to abundant natural forest resources under a regime of weak law enforcement has been a disincentive for tree growing. Forest industries and wood exports are still largely dependent on natural forests, although the significance of forest plantations has been increasing along with the natural forest degradation (Lestrelin et al. 2013). Data on demand-supply balance in Laos is largely inconsistent and unreliable, but it is evident that log exports have been - and still are - far larger than reported, and logging volumes considerably larger than quotas (The World Bank et al. 2001; Saunders 2014). Even though the forest area has slightly increased since 2000 despite decades of deforestation, the increase is mainly explained by the increase in rubber plantation area (Phimmavong 
et al. 2009; Kenney-Lazar 2012; FAO 2015). The remaining natural forests are degrading at an alarming rate as the transition of forest areas to the 'potential forest' ${ }^{2}$ category continues (FAO 2015). In 2018 the Annual Allowable Cut for commercial species in 51 Production Forest Areas $^{3}$ is estimated to be as low as $40000 \mathrm{~m}^{3}$ (Department of Forestry unpublished data).

Some $80 \%$ of households use wood as their primary energy source and natural forests still provide enough fuelwood for the country. However, village's natural forest resources ${ }^{4}$ are degrading and unable to meet the household timber needs, thus household timber is considered as an important secondary purpose for teak plantations after commercial growing (Hansen et al. 1997; Midgley et al. 2017).

\section{Exports and Industries}

Laos has become a resource frontier for China, Vietnam and Thailand (Lestrelin et al.

2 "Potential forest" refers to degraded and temporarily unstocked forest with a crown cover below 20\%; their share of the total forest area was estimated at 52\% in 2015 (FAO 2015).

${ }^{3}$ Production Forest Areas (natural forest designated for production) cover 3.2 million ha or some $34 \%$ of the total forest area. Forest plantations are included in the production forest category but are not included in this figure.

${ }^{4}$ Households have an annual quota to cut trees for home consumption (construction, fuel wood) from the 'village forest' that their village is entitled to manage and use. Village forests are not necessarily large enough to supply the needs of all villagers, quotas are often exceeded, and quotas have also been used for commercial logging (illegally). 
2013), with wood products accounting for $28-56 \%$ of official exports from Lao PDR in the 1990's (The World Bank et al. 2001; Smirnov 2015). The government introduced an export ban for roundwood in 2007 to promote the development of the domestic wood processing industry, but the impact has been negligible. Plantation-grown wood is exempted from the ban if it cannot be processed domestically, and simplified certification procedures can be applied to the export process. The National Export Strategy 2011-2015 targets wood products as being a sector having potential to generate foreign exchange, with a consequent regulation on exports and imports and on chain of custody requirements for plantation wood (Smith et al. 2017). Today the wood industry still consists of small and medium sized sawmills, furniture factories, and plywood and other wood-based panel production (Redman et al. 2014).

The export volume of all teak products in 2013 was approximately $13000 \mathrm{~m} 3$, mainly to China and Thailand (Midgley \& Mounlamai 2015). It is estimated that the smallholder teak plantations in northern Laos supply annually some 10,000 m3 of roundwood for small wood processing industries and exports (Midgley \& Mounlamai 2015).

\section{Capacity and Knowledge on Tree Growing}

Support services for smallholder tree growing have remained weak. For instance nursery capacities and technologies are underdeveloped (Prime Minister's Office 2005). Over the years only specific projects (such as the Luang Prabang Teak Programme, LPTP and ACIAR VALTIP programmes ${ }^{5}$ ) have been able to deliver high quality

\footnotetext{
${ }^{5}$ http://laoplantation.org/valtip3/about-us/project-background/
} 
seedlings and trainings for tree growers (Van Gansberghe et al. 2011). District Agriculture and Forestry Offices (DAFOs) are responsible for the extension services delivery, but their capacity and resources have remained low and depend on (donor) project funding (Vannasou 2006).

\section{Farmer and Tree Grower Organisations and their Capacities}

Farmer organisations are promoted by the agricultural and forestry strategies, and they have a strong legal framework established in specific legislation (Smith, Ling, et al. 2017). However, the policy and legislation have not materialised into field-level advisory support to Tree Grower Associations establishment and organisational development (TGAs) (Ling et al. 2018). Limited benefits received in return for the organisation, registration and associated fees may lower tree growers' interest in associations, despite the tax incentives and exemptions applied to farmer cooperatives and enterprises (Ling et al. 2018).

\section{Incentives}

Soft loans have been made available for smallholders for tree growing and agricultural activities in the context of the Land Allocation Programs. Loans are not commonly used for tree plantation investments and, for example, experiences from the Asian Development Bank's Industrial Tree Plantations Project 1995-2005 on smallholder tree growing credits were very poor (Nevins \& Peluso 2008). The land allocation

programme has been the most extensive incentive for tree growing, but in the process of land allocation, tree growing has also been a way for village elites and non-resident land speculators to claim additional land (Sacklokham \& Dufumier 2006). According to Hansen et. al. (1997) and Midgley et al. (2007) the possibility to use teak plantations as collateral or sell the plantation to investors has attracted some smallholders to plant. 
Smallholder woodlots are often too small, or their stocking is too low, and they lack formal registration to qualify for tax exemptions. The monetary value of the exemption from land tax is low compared to all fees, charges and taxes in land registration and tree growing, harvesting and sales (Smith, Barney, et al. 2017). Furthermore, provincial and district authorities apply the legislation differently, and may also have additional local taxes that override the national-level exemptions.

\section{Case study: Luang Prabang and Vientiane Province Teak Growers}

After analysing the operating and enabling environment the study focused on field level: how the changes of the enabling environment and its present status have influenced tree growing in villages in Luang Prabang and Vientiane provinces?

\section{Case-study Methods}

Definitions of smallholder tree growing and plantations vary and are also country specific (Harrison \& Herbohn 2002). In this paper 'smallholder tree growers' refers to households that own at least one woodlot larger than 0.1 ha, with their total tree growing area being less than 20 ha. To decrease dispersion in the sample, trees grown in permanent agroforestry systems, involving permanent cultivation of crops with teak, are not included.

\section{Research Area}

Luang Prabang Province was selected because of its long tradition of teak growing, while Vientiane Province was selected because of its proximity to the capital and the main national markets, which have stimulated teak plantation development in the area (Hue et al. 2017). Four study villages were purposively selected for this research; three in Luang Prabang (Ban En, Ban Xiengloum, Ban Thinsom) and one in Vientiane 
(Phialat) (Figure 1) to represent variation in access to markets and extension support

(Table 1). Selection was made in collaboration with the Luang Prabang Teak Programme and the National University of Laos. The field work was carried out in October-November 2015.

[Figure 1 near here]

[Table 1 near here]

In each village 15 'teak growers' and 15 'non-growers' were randomly selected from a list formulated by the village head, with ranking of groups into three socioeconomic sub-groups: high, middle and low-income households. The listing was supported by the village household records. The socioeconomic ranking was subjective, but on the other hand also reflects the perception of living standards in the region and in the village. Income sub-grouping was only used to diversify the sample of interviewees, not in the data analysis. For practical reasons absentee land owners could not be interviewed.

\section{Data Collection and Analyses}

The interviews were organized either at the respondent's home or at the village 'meeting house' with each interviewee on a one-on-one basis. Each interviewee was asked for their willingness to participate in the research and permission to record the interview. The semi-structured interviews were carried out based on a questionnaire (see Annex 1-supplemental material) covering household's basic information, income sources and their importance, farming, detailed information on woodlots and their establishment, and management, extension, drivers and challenges of tree growing and future perspectives. Interviews were conducted in Lao language by a local extension officer with the support and presence of a research team member. Whenever possible, 
the team visited interviewees' teak plantation ( $58 \%$ of the owners) to cross check and validate their answers on site quality, plantation management and condition, and to estimate basic stand-level variables. In $42 \%$ of cases difficult access/remote location prohibited site visits. This causes a slight risk for the reliability of some answers (e.g. on management) but does not influence the main questions analyzed in this study.

Because the sample size is small and sampling methodology contains subjective elements, the statistical analysis in this research is limited to descriptive methods and methods applicable to small samples (Mann-Whitney U-test, Spearman correlation, Chisquare).

Market data on teak was collected through interviews with middlemen (7) and teak processors (4), and from provincial government records. The information is patchy and only gives a general overview because most wood sales do not follow the formal procedures for licencing, and as such these volumes and prices are not recorded.

\section{Results}

\section{Socioeconomic characteristics of the interviewed tree growers and non-growers}

There were no statistically significant differences in socioeconomic variables between the tree growers and non-growers groups, but there were significant differences in income and agricultural land within the non-growers group. In general, tree growers had more land and they were also more often using external labour in farming activities (Table 2). In the non-growers' group $28 \%$ of the households had no land, and $17 \%$ had less than one hectare. Nearly all interviewees in both groups $(89 \%)$ had formal land rights either through occupancy or permanent land title. The share of landless families was especially large in the non-grower groups in Phialat and Ban En villages, leading to 
significantly less rice self-sufficiency among non-growers.

[Table 2 near here]

Most households had cash income both from agriculture and livestock, and businesses and/or labour work. According to the rough estimates the interviewees gave on the share of each income source, in the tree-growers' group 58\% had agriculture (cropping and livestock) as the main income source (i.e. $\geq 50 \%$ of their income), with the remaining $42 \%$ reporting that business and labour work were the most important income sources. In the non-growers group the shares were $22 \%$ from agriculture and $78 \%$ from business and labour work. Variation between villages was large (Figure 2), reflecting local availability of labour work and business opportunities, and land availability. Income from timber sales is significant but occasional for tree growers, with timber sales often taking place only when the household needs to invest or has unexpected expenses, or when the owner receives a tempting offer from a buyer.

[Figure 2 near here]

\section{Teak planting in the study villages}

Teak planting areas clearly increased in 1993-1995 among the teak growing interviewees, with some increase being also observed in 2000 and again in 2005-2008 (Figure 3). However, no major differences are identifiable between the villages, although in Phialat less woodlots were established during the first peak. Only a few of the tree growers had rubber plantations, or tree plantations other than teak.

Most of the interviewed households had one (45\%) or two $(26 \%)$ woodlots, with 
six being the maximum number of woodlots of any household. Nearly $60 \%$ of woodlots owned by the interviewees were smaller than 1 ha and the plot average area was 1.1 ha.

[Figure 3 near here]

The majority of the woodlots are on former agricultural (59\%) or fallow land (20\%). The rest have been established on former grass or grazing land or are replanted tree plantations. Seedlings had been mainly produced from stumps prepared from wildings collected from existing plantations in the village. Intercropping was common, with $81 \%$ of tree growers having planted agricultural crops (e.g. rice, Job's tears ${ }^{6}$, pineapple) during the first years of tree plantation establishment. The majority of interviewees (89\%) carried out regular weeding, slashing and pruning of their woodlots, but only one third (29\%) did thinning. On the site visits it could be observed that thinning meant mostly removal of dead trees or cutting a few trees, e.g. for household use. Only five of the interviewees doing thinning had received extension advice on the topic. A common practice is to let the teak plantations coppice after a selective cut, which was observed at some of the visited woodlots.

\section{Motivation for tree growing}

Teak is grown primarily for timber sale ( $69 \%$ of all respondents), with one third also mentioning own use as the secondary purpose. Several interviewees, including village head men, stated that the village forest resources are degraded and cannot supply the villagers with enough timber. Only one tree grower mentioned that tax exemption

\footnotetext{
${ }^{6}$ Coix lacryma-jobi
} 
benefits had been a motivation to plant trees. None of the interviewed tree growers had received any loan for their plantation investment, nor mentioned the option to use their tree plantations as collateral as a motivator to plant trees. Instead, whole plantations had been sold in times of urgent cash needs (safety net/savings account).

\section{Extension services for tree growers}

Slightly more than half $(55 \%)$ of the interviewed tree growers had received forestry extension services, mainly through a project or programme implemented with external (donor) finance. Very few interviewees (7) mentioned district forestry extension as the source of services. Topics of extension services were mainly early management, pruning and thinning.

The LPTP program supported the establishment of TGAs between 2008 and 2014 in Ban En and Xienglome, where 69 and 53\% of the interviewed teak growers are TGA members respectively. In Thinsom, a non-LPTP village, $56 \%$ are TGA members, in Phialat none as there is no TGA in the village. Very little reference was made to the association and the interviewed teak growers seemed to consider membership as a precondition to access LPTP support services.

\section{Market access}

Nearly half (48\%) of the tree growers had sold teak at least once (between 1997-2014), mostly some dozens of trees of 20-30 cm diameter to a middle-man, or in some cases directly to a wood processor/manufacturer. Despite the classification of $\mathrm{Ban}^{\mathrm{En}^{7} \text { as a }}$

\footnotetext{
${ }^{7}$ Official village name is Ban Ensavanh, spelling forms of the shortened name used include 'Ban Ean' and 'Ban Enh'. Google maps uses the shortened name 'En'.
} 
remote village, there was a wood processing enterprise in the village and several export oriented larger processors near the village. Inventory for wood sales was rarely done (although it is required by law), and varying methods were used for measuring trees and setting prices. Overall, the interviews with middlemen and tree growers revealed that tree growers had very little room to negotiate wood sales. Middlemen rarely bought all the trees (i.e. clear cutting was rare), but instead the contractor selectively cut the best quality trees. The owners were left with the remaining trees to grow and regenerate new trees from stumps via coppicing. Sometimes middlemen also bought trees in advance to be harvested later if the seller needed more money than received from the mature, higher quality trees. The interviewees reported that the process of selling their wood was quite easy, and middlemen easy to contact and work with. Interviewees considered middlemen important and their services essential, as they took the responsibility of the bureaucratic process. Only four interviewees mentioned having received extension support in wood sales or measurement. LPTP has been working to establish and extend the sales network with middlemen but this did not come up in the tree grower statements as an extension service.

The interviewed forest industry representatives reported that teak prices are higher in northern Laos due to the influence of Chinese traders and plantation investments. This was reflected in disappointing experiences in Phialat (in central Laos), where local traders offered relatively low prices for teak.

\section{Future of teak growing}

Although the tree growers had reasonably high interest to expand their tree growing area in Phialat, most of them were planning to change species from teak to fruit trees or Dipterocarps. In Ban En tree growers preferred teak for their future/planned tree 
growing, whereas in Thinsom and Xienglome some teak growers were planning to change species, mentioning oil palm and Dipterocarps as alternatives. Interest to expand tree growing areas was the lowest in Xienglome, reflecting constraints in land availability, which was listed as the main reason not to plant trees in all villages. The majority of tree growers $(63 \%)$ considered agriculture, (cash crops including fruit trees and oil palm) as being a more profitable land use because of the steady, annual income.

\section{[Table 3 near here]}

It was clear among the tree growers that the (land) tax exemption benefits are not sufficient to attract people to plant trees as they were only mentioned once in the interviews as a benefit in tree growing. Most tree growers said that if available, they would apply for incentives such as extension services and tools or seeds/seedlings.

One third of the non-growers expressed interest to grow trees in comingyears; the main reason for not being interested in tree growing was lack of land. In this study, we did not identify clear dependencies between the socioeconomic factors and tree growing interest, but the decision is a complex combination of factors. The main motivation for future tree growing in both groups was to increase income or to leave assets for children. Teak was clearly the most preferred species among non-growers, but rubber and fruit trees were also mentioned. Most of the non-growers said they have sufficient tree growing knowledge, and are aware of the incentives. For technical advice they would turn to other villagers or District Forestry Officer. Only $15 \%$ of the tree growers that were interested in expanding their tree growing area considered incentives (extension, seeds/seedlings) to have a significant influence on their decisions about tree growing. In the non-growers' group only one interviewee said incentives are important, although most of them were interested in applying for them, if available. 
[Table 4 near here]

\section{Discussion}

Land regulations have remained basically the same since the 1990's, as well as the tax exemptions for tree growing, even though the overall regulatory framework for plantation forestry has gradually become a complex jungle of laws, orders and regulations (Smith, Ling, et al. 2017). The land rights and land allocation policy introduced in the early 1990's, as well as the Land and Forest Law revisions in mid2000's, seem to have created secure enough land and tree tenure and induced teak growing in the study villages, but the complex regulations have counteracted the land incentives (Smith, Barney, et al. 2017).

In line with the findings of Dieters et al. (2014), off-farm income and rice selfsufficiency - in combination with access to land - encourages households to invest in tree growing in our study villages. Trees are grown primarily to create additional income through timber sale, although domestic use is also an important secondary use, similarly as in Hansen's study (1997). Compared to previous studies, securing land use rights was no longer an important motivator for tree planting, nor was the option of using tree plantation as collateral (Newby et al. 2012).

Based on our findings the land use planning and land allocation program as it is implemented now no longer allows smallholders access to additional land for tree growing, even though tree growing areas among the interviewed households rarely reached the limits set in the legislation for the maximum area per capita. Whether this is due to complexities in the allocation procedures, lack of awareness, land scarcity, land conflicts, or quality of available lands, or authorities' reluctance, are questions that need further research. The majority of the woodlots owned by interviewed farmers are not 
eligible for exemptions because they are unregistered: due to their small size plantation registration is simply unfeasible as the annual land tax is low compared to the registration payment (Smith, Ling, et al. 2017). Additional tax benefits for TGAs seem to be equally negligible. This is in line with findings of Ling et al. (2018) who showed that the benefits the TGAs are able to provide vs. the time invested in TGA activities are not sufficient to attract smallholders' interest.

Export demand (from China) for smallholder teak in Northern Laos is strong (Midgley \& Mounlamai 2015) but the challenge is that teak requires fertile soil and tree growers are speculating with the opportunity costs to optimize their land uses between agriculture and different types of tree plantations. Intercropping is a common practice to have income also during the first years of the tree plantation.

Government extension services were rarely referred to as an information source. This reflects an absence of the services but as the majority of smallholder tree plantations are unregistered in Lao PDR, could possibly indicate also aspirations to avoid interaction with government authorities and hence avoid complicated and costly registration and licencing procedures (Smith, Barney, et al. 2017).

Although tree growers saw middlemen positively, lack of transparent and competitive timber markets is a barrier to improve timber quality and yield. Due to poor timber quality smallholders are not able to sell all their trees and/or the price received is low, which also creates a vicious cycle as the plantations are not re-established properly (Bouaphavong et al. 2016). Low timber quality leads to a weak competitive position of Lao teak in the international market (Anttila 2016). Plantation management practices have remained the same over the years thus advisory services have not sufficiently reached and convinced tree growers to improve their practices. Many farmers are 
tempted to change to more productive agricultural land uses. The prevailing management and sales practices leave them with thinly stocked, low quality and unproductive teak plantations which increases the comparative advantage of other land uses.

Strong Chinese demand maintains the teak growing interest in Luang Prabang Province, although it is not likely to increase among the interviewed smallholders without access to more land. In Phialat tree growers are planning to change from teak to fruit trees, or other native tree species due to lower teak prices. Incentives are mainly considered insignificant for tree growing, signalling a need to review them to meet smallholder needs. Smallholders think that they already have enough knowledge on teak growing, thus the challenge in improving the plantation management and tree quality to better meet the market and industrial needs is not only in the access to extension services but also in changing smallholders' attitudes.

\section{Conclusions - Recommendations}

The government of Laos has not fully succeeded in establishing and improving the enabling environment for smallholder tree growing, and in turning policies into tangible incentives. Land and tree tenure is considered safe but the tree growing incentive created by the land allocation programme is currently dissolving because of the reducing availability of land, possibly because external investors and larger concessions are favoured in land allocation (Hett et al. 2015) and Chinese demand may not alone be able to maintain and increase tree growing interest. The complicated regulatory framework is also a bottleneck for smallholder tree growing. In this context, the on-going forest law revision process is in a key position to improve the operating 
environment.

The motivations and practices of teak growing have not changed in the study area since Midgley and Brown (2007) studied Xiengloum and Ban En villages in 2006. In Xiengloum land availability is becoming a limiting factor for tree growing, with households possibly reaching a 'saturation' with teak plantations as majority of village households already have teak. Improved infrastructure, growing tourism and business opportunities in Luang Prabang region, and increasing demand from China have increased both employment, business and cash crop options for farmers. This may decrease land owners' interest to grow trees, but it may also increase this interest: with secure employment or business income they often plant trees to maintain land under productive use (and ownership) with minor labour inputs.

Smallholder tree growers are not able to fully benefit from the wood markets as their negotiation power is weak. Their position could be improved through improved plantation management focusing on quality, and through improved organisation under TGAs with attractive services. Agroforestry systems with teak are under research and this could also provide a way to change the practices and meet smallholder interests.

Demand for short rotation agricultural cash crops is high, and they are often the preferred option due to the regular income they provide. It remains to be seen how social changes and market fluctuations will alter the land use preferences in coming years. Considering the ongoing degradation of village forest resources, manifested in smallholder's emerging interest to grow Dipterocarps in plantations, the importance of smallholder plantations in meeting the domestic needs is likely to increase.

Smallholders prefer native species for timber growing and are starting to 
recognize the impact of declining natural forest resource on timber markets, hence Dipterocarps could open up interesting future opportunities for forest rehabilitation, which is in line with the present government policy promoting native species growing.

The present practices of land allocation and how they meet smallholder expectations call for further research. If smallholder tree growing remains in the political agenda, thorough revision of LUPLA and investments in extension support in terms of both inputs and advisory services would be necessary for any expansion or introduction of new smallholder tree growing schemes. 


\section{Acknowledgements}

We thank FoLAFI project, funded by the CIMO N-S-S program and coordinated by VITRI, University of Helsinki in collaboration with the National University of Laos (NUoL), for making the field work possible.

Special thanks to Pheng Sypaserd (Department of Forest Inspection), Mr. Vansy Phengthajaim (NUoL), Mr. Phonekham Siphommachanh (ACIAR), Mr. Sisuthone Oupaxayorvanh (NUoL), and Mr. Souksompong Prixar (NuoL) for assistance and coordination during the field work. We also wish to thank the Academy of Finland for partial funding support for this work during the analysis and writing phase via research project number 277182 (GET-LDC project). We also thank Ms Maarit Kallio and Professor Markku Kanninen for their useful comments on the manuscript. 


\section{References}

Andersson M, Engvall A, Kokko A. 2009. In the Shadow of China: Trade and Growth in Lao PDR. Stockholm: Stockholm School of Economics.

Anttila JP. 2016. Implications of middlemen in smallholder teak production systems in Northern Lao People's Democratic Republic (Lao PDR). Helsinki: University of Helsinki.

Bauhus J, Van Der Meer P, Kanninen M. 2010. Ecosystem Goods and Services from Planted Forests. Bauhus J, Van Der Meer P, Kanninen M, editors. London: Earthscan.

Boer K, Seneanachack H. 2016. Mapping and Characterisation of Plantation Teak in Luang Prabang Province, Lao PDR. Canberra: ACIAR.

Bouaphavong D, Veenin T, Jarusombuti S. 2016. Teak Log Grading for Teak Plantation in Lao PDR. Thai J For. 35:160-169.

Bourdet Y. 1995. Rural Reforms and Agricultural Productivity in Laos. J Dev Areas. 29:161-182.

Byron N. 2001. Keys to smallholder forestry. For Trees Livelihoods. 11:279-294.

Cossalter C (Cifor), Pye-Smith C (Cifor). 2003. Fast-wood forestry: myths and realities. Bogor: CIFOR.

Cramb R, Manivong V, Newby J, Sothorn K, Sujang P. 2015. Alternatives to Land Grabbing: Smallholder Engagement in Commodity Booms in Southeast Asia. Chiang Mai, Thailand: Conference proceedings from an international academic conference; 5-6 June 2015; Chiang Mai. BRICS Initiatives for Critical Agrarian Studies (BICAS). 
Delang CO, Toro M, Charlet-Phommachanh M. 2013. Coffee, mines and dams:

Conflicts over land in the Bolaven Plateau, southern Lao PDR. Geogr J. 179:150-164.

Dieters M, et. Al. 2014. Enhancing on-farm incomes through improved silvicultural management of teak in Luang Prabang Province of Lao PDR. Canberra: ACIAR.

Ducourtieux O, Laffort J-R, Sacklokham S. 2005. Land Policy and Farming Practices in Laos. Dev Change. 36:499-526.

Earth Systems. 2016. Lao PDR Eucalypt Sector Discussion Paper, Towards Sustainable Forest Management: An Industry Perspective. Vientiane: Mekong Region Land Governance Project (MRLG).

Enters T, Durst PB, Brown CL. 2006. Stimulating forest plantation development through incentives - in search of the elusive blueprint for success. In: Appanah S, Mansur E, Krezdorn R, editors. Strateg Financ Mech Sustain use Conserv For Exp from Lat Am Asia. Chiang Mai, Thailand: FAO; p. 102-119.

FAO. 2015. FRA 2015 - Country Report, Lao People's Democratic Republic. Rome.

Friis C, Nielsen JØ. 2016. Small-scale land acquisitions, large-scale implications: Exploring the case of Chinese banana investments in Northern Laos. Land use policy. $57: 117-129$.

Van Gansberghe D, Krantz L, Phanvilay K. 2011. Evaluation of the Upland Research and Capacity Development Programme in Laos. Vientiane: Sida.

Guttal S. 2011. Whose lands? Whose resources? Development. 54:91-97.

Hansen PK, Houmchitsavath S, Savanthavong S. 1997. Teak production by shifting 
cultivators in Northern Lao PDR. Luang Prabang: Lao Swedish Forestry Programme.

Harrison S, Herbohn J. 2002. Non-industrial, Smallholder, Small-scale and Family Forestry: What's in a Name? Small-scale For Econ Manag Policy. 1:1-11.

Hett C, Nanhthavong V, Saphangthong T, Robles GR, Phouangphet K, Speller W, Messerli P, Epprecht M, Heinimann A. 2015. Land deals in Laos: First insights from a new nationwide initiative to assess the quality of investments in land. In: L Grabbing, Confl Agrar Transform Perspect from East Southeast Asia. Chiang Mai, Thailand: Proceedings of an international academic conference; 5-6 June 2016; Chiang Mai. BRICS Initiatives for Critical Agrarian Studies (BICAS).

Hue S-W, Korom A, Seng Y-W, Sihapanya V, Phimmavong S, Phua M-H. 2017. Land Use and Land Cover Change in Vientiane Area, Lao PDR Using Object-Oriented Classification on Multi-Temporal Landsat Data. Adv Sci Lett. 23:11340-11344.

Hurni K, Hett C, Heinimann A, Messerli P, Wiesmann U. 2013. Dynamics of Shifting Cultivation Landscapes in Northern Lao PDR Between 2000 and 2009 Based on an Analysis of MODIS Time Series and Landsat Images. Hum Ecol. 41:21-36.

Kallio MH, Hogarth NJ, Moeliono M, Brockhaus M, Cole R, Waty Bong I, Wong GY. 2019. The colour of maize: Visions of green growth and farmers perceptions in northern Laos. Land use policy. 80:185-194.

Kenney-Lazar M. 2012. Plantation rubber, land grabbing and social-property transformation in southern Laos. J Peasant Stud. 39:1017-1037.

Lamb D. 2015. Regreening the Bare Hills. Tropical Forest Restoration in the AsiaPacific Region. Dordrecht: Springer Science+Business Media. 
Lao People's Democratic Republic. 2007. Forestry Law. Lao PDR.

Lestrelin G, Trockenbrodt M, Phanvilay K, Thongmanivong S, Vongvisouk T, Pham Thu T, Castella JC. 2013. The context of REDD+ in the Lao People's Democratic Republic: drivers, agents and institutions. Bogor: CIFOR.

Ling S, Smith H, Xaysavongsa L, Laity R. 2018. The Evolution of Certified Teak Grower Groups in Luang Prabang, Lao PDR: An Action Research Approach. Smallscale For. 17:343-360.

Ling S, Xaysavongsa L, Chandiphit S, Phonchaluen S. 2016. The Evolution of Certified Teak Grower Groups in Luang Prabang, Lao PDR: An Action Research Approach. Melbourne.

McDermott CL, Cashore B, Kanowski P. 2009. Setting the bar: an international comparison of public and private forest policy specifications and implications for explaining policy trends. J Integr Environ Sci. 6:217-237.

Midgley S, Brown A. 2007. Towards improving profitability of teak in integrated smallholder farming systems in northern Laos. Canberra: ACIAR.

Midgley S, Mounlamai K. 2015. Global Markets for Plantation Teak; Implications for Growers in Lao PDR. Canberra: ACIAR.

Midgley SJ, Stevens PR, Arnold RJ. 2017. Hidden assets: Asia’s smallholder wood resources and their contribution to supply chains of commercial wood. Aust For. 80:1025.

Ministry of Agriculture and Forestry. 2010. Strategy for Agricultural Development 2011 to 2020. Sector Framework, Vision and Goals. Vientiane. 
National Assembly. 1996. The Forestry Law. Lao PDR:

https://www.wto.org/english/thewto_e/acc_e/lao_e/WTACCLAO3A1_LEG_5.pdf.

Nevins J, Peluso NL. 2008. Taking Southeast Asia to market: commodities, nature, and people in the neoliberal age. Nevins J, Peluso NL, editors. Ithaca \& London: Cornell University Press.

Newby JC, Cramb RA, Sakanphet S, Mcnamara S. 2012. Smallholder Teak and Agrarian Change in Northern Laos. Small-scale For. 11:27-46.

Phimmavong S, Ozarska B, Midgley S, Keenan R. 2009. Forest and plantation development in Laos: history, development and impact for rural communities. Int For Rev. 11:501-513.

Phompila C, Lewis M, Ostendorf B, Clarke K. 2017. Forest Cover Changes in Lao Tropical Forests: Physical and Socio-Economic Factors are the Most Important Drivers. Land. 6:23.

Prime Minister's Office. 2005. Forestry Strategy to the Year 2020 of the Lao PDR. Vientiane.

Redman A, Hopewell G, Bouaphavong D. 2014. Current production practices and processing efficiency. Canberra: ACIAR.

Sacklokham S, Dufumier M. 2006. Land-Tenure Policy, Deforestation, and Agricultural Development in Lao PDR: the Case of the Vientiane Plain. Moussons.:189-207.

Saunders J. 2014. Illegal Logging and Related Trade: Measuring the Global Response in Lao PDR. London: Chatham House. 
Smirnov D. 2015. Assessment of Scope of Illegal Logging in Laos and Associated Trans-Boundary Timber Trade (Unpublished). Vientiane.

Smith H, Barney K, Byron N, Van Der Meer Simo A, Keenan R, Vongkhamsao V. 2017. Tree Plantations in Lao PDR : Policy Framework and Review. Canberra: ACIAR.

Smith H, Ling S, Boer K. 2017. Teak plantation smallholders in Lao PDR: what influences compliance with plantation regulations? Aust For. 80:178-187.

Stuart-Fox M. 2007. Laos: Politics in a Single-Party State. In: Singh D, Salazar LC, editors. Southeast Asian Aff 2007. Vol. 34. Singapore: ISEAS-Yusof Ishak Institute; p. $159-180$.

The World Bank, Sida, Ministry for Foreign Affairs of Finland. 2001. Lao PDR Production Forestry Policy. Status and Issues for Dialogue. Vientiane.

Vannasou T. 2006. The development of extension in Lao PDR. In: Petheram RJ, Johnson RC, editors. Australas Pacific Ext Netw. Beechworth, Victoria: La Trobe University; p. 1-10.

Vongvisouk T, Lestrelin G, Castella J-C, Mertz O, Broegaard RB, Thongmanivong S. 2016. REDD+ on hold: Lessons from an emerging institutional setup in Laos. Asia Pac Viewp. 57:393-405.

${ }^{\text {i }}$ Luang Prabang Teak Programme (LPTP) started in 2008. LPTP is supporting sustainable forest management to achieve FSC-certification status for smallholder teak. Program's impact is locally significant through professional extension services and 
organisation of tree growers although benefits of certification are limited to a smallholder in Lao PDR (Ling et al. 2018; Midgley et al. 2017).. 